\title{
A Study on the Decision Making Process in Public and Private Broadcast Newsrooms in Malaysia
}

\begin{abstract}
By Roslina Abdul Latif*
The decision making process in the newsrooms based on interpretation, influence and pervasiveness of the news from different media organizations is unarguable. This study examines the decision making process in the public and private newsrooms of three major broadcasting houses namely TV1 and TV3 to determine the process of how this happens. The objectives of this study is to identify the changes that have taken place in the editing policies, to explore the internal and external factors that have influenced the decision making process and to study if news programming patterns have changed since Najib's reign as Prime Minister and which government policies have influenced the network's programming. This study engages in several qualitative methodologies specifically in-depth interviews and document analysis. Notable editors, chief editors and group editors gave in-depth interviews on their decision making process and issues that 'dampen' the process of nation building in shaping the trajectory of the news. The findings showed that the decision making process in these three newsrooms are made through consensus by a specific group of people. Two daily meetings are conducted on a daily basis to determine news coverage and headlines. Although it sounds simple but there are internal and external factors that influence the decision making process. While government broadcast newsrooms predominantly runs on the government model, the private broadcast newsrooms follow the professional model but with different approaches. Media organizations give coverage to all government policies as and when it happens and not as a daily routine. The study implies that decision-making made under policy considerations are more stringent in terms of control, procedures and protocol in Malaysia.
\end{abstract}

\section{Introduction}

Author and news executive Jack Fuller writes: "The central purpose of journalism is to tell the truth so that people will have the information that they need to be sovereign" (Gans, 2003). This statement is true as we rely on news media especially in times of crisis. A good example was during the September 11, 2001 disaster where journalists responded quickly and professionally. The

${ }^{*}$ Lecturer, Taylors University Lakeside Campus, Malaysia. 
horrifying details of the terrorist attacks on New York's World Trade Center and the Pentagon in Washington D.C. was conveyed rapidly to a global audience in print, the Internet, by radio and by vivid color in television. Virtually the same horrific footages were seen and shocking reports were heard as in the States.

Although the news media in Malaysia may seem lacking in coercive power as they cannot literally draft journalists to war torn nations or do coverage on crisis nations but this has changed considerably in recent years. This was proven recently during the attacks on Sabah. As we deployed our police and army personnel, we also deployed our team of journalist to cover news on the ground. Their influence and pervasiveness are indisputable. Yet there are still disagreements and conflicting views about just how the public is influenced by the media in general by the news written by the journalist in particular and the stories produced by the editors specifically.

Often thought to be glamorous and powerful individuals, journalists in general are hard-working, often harried people with little time for and even less patience with, the glamour of being on television (for the broadcast journalists). They are dedicated professionals ever conscious of their responsibilities to the job and their audience. They have more power than the rest of us mainly because they express and often subscribe to, the economic, political and social ideas and values which are dominant to Malaysia.

\section{The Newsroom}

\section{Identifying Story Selection}

Story selection is a decision-making and choice-making process albeit a hurried one. As a result, the considerations must be quickly and easily applicable so that choices can be made without too much deliberation (Gans, 1980). Many theories have been put forth about how the selection of stories is routinized. Gans (1980) puts forward five theories of story selection. They are journalist-centered, routinization based on organizational requirements, eventcentered, technological, economic and ideological determinants, and external factors.

Story selection for broadcast news in Malaysia depends on a few considerations and the suitability of the stories for the day's transmission. It has always been a policy in newsrooms to carry news of the Prime Minister and Deputy Prime Minister in the first block of the news bulletin regardless whether it is a 30 minute or an hour's bulletin. The rest of the news bulletin will follow the line-up in terms of importance and news worthiness. The buildup of the line-up has been described by editors as a 'train' where the main stories act as the head of the locomotive while the other stories hook-up and make the rest of the bulletin. This would generally be the main news, business news, foreign news, sports news and the closing (Roslina and Faridah, 2012).

Other considerations include either adding stories or dropping them depending on the latest breaking news. According to Gans (1980) this 
consideration must also be easily rationalized so one story is replaced by another and an acceptable reason for doing so is always at hand. These considerations are also designed with the efficiency so as to guarantee the necessary supply of suitable news with the least amount of time, effort and if possible expenditure.

\section{Conceptualizing Decision Making}

There are many concepts of decision making. Morris (1964) and Simon (cited in Dimmick \& Coit 1982) although years apart, define decision making as a model or logical structure which is used to bring some conceptual order out of the endless variety of observations that steers the course of society and its economic and government organizations. It is work of choosing issues that require attention, setting goals, finding or designing suitable courses of actions and evaluating and choosing among alternative actions.

Gans (1980) description of the decision making process is story selection and choice, notwithstanding a hurried one. Gans quotes Edward J. Epstien's research at NBC News, that if journalists had to treat the hundreds of choices they make every day as formal decisions, they would be unable to complete their work. They instead act on the basis of quick, virtually intuitive judgments which some ascribe to "feel" or "gut feelings".

Zey describes the theory of problem solving and decision making as centrally concerned with how people cut problems down to size: how they apply approximate, heuristic techniques to handle complexity that cannot be handled exactly (Zey, 1992).

A decision may be defined most simply as a choice between two or more alternatives. In practice, more than two alternatives are often involved but all the typical problems of decision making arise when at least two alternatives typically leads to some form of behavior that is consistent with the choice, a decision does not requires such consistency. Finally the choice between alternatives need not be based on any rational process of assessment and evaluation even though there is much to be said in favor of such rational processes. A group decision then is naturally defined by means of preceding definitions as a choice between two or more alternatives made by group members or by a group leader in consultations with the membership. If neither of these conditions is satisfied, then even though a group exists and decision has been made, we will not characterize such a choice among alternatives as a group decision (Group Decision Making, 1984).

\section{Background of Selected Media Organizations}

The two media organizations that are studied in this paper are TV1 from Radio Television Malaysia (RTM) and Sistem Television Malaysia (TV3). We simply cannot dwell further into this research without taking a look at the background of these organizations and more importantly the question of 
ownership as it is obviously an effective way to affirm control over any entity including the media establishment.

\section{Radio Television Malaysia (RTM)}

Radio Television Malaysia or better known as RTM is a government owned television network. It broadcasts from its headquarters in Angkasapuri, Kuala Lumpur. RTM owns and operates a number of radio and television stations. At present, it runs 6 national, 2 international, 17 states, 11 district radio stations and 2 television channels - TV 1 and TV 2 (RTM, 2011). When it started transmission on 1st April 1946, RTM was established as Radio Malaya operating out of Singapore. On 31st August 1957 when Malaya received its independence, Radio Malaya was split into two with the original studios in Singapore taken over by a new station called Radio Singapura while Radio Malaya moved to Kuala Lumpur going on air from the new location on 1st January 1959 (RTM, 2011).

Radio Malaya was later named Radio Malaysia on 16th September 1963 with its signature transmission trademark words Inilah Radio Malaysia (This is Radio Malaysia). Services rendered under Malaysia Television (Malaysia TV) started on 28th December 1963 in the Klang Valley and Selangor. The 10 month old Television Singapura which was launched on 16th February 1963 became part of Malaysia Television till 1965 when Singapore broke away from Malaysia (Penyiaran, 1987). Radio Malaysia later became Rangkaian National (National Channel) on 1st January 1971 and became the nation's first 24 hour radio station. In 1978 Rangkaian Satu (Network One) was renamed Malaysia Television Satu (Malaysian Television One). A year later Rangkaian Dua (Network Two) was renamed Malaysia Television Dua (Malaysian Television Two). New separate logos for both networks were launched in the same year. The following year, Malaysian Television and Radio Malaysia merged to become Radio Television Malaysia, RTM (Penyiaran, 1987).

\section{Sistem Television Malaysia Berhad (TV3)}

While privatization is a goal in the business sector, a free press without government restrictions is not. The government controls the press, broadcasting houses and the publishing enterprises throughout Malaysia. Strong political and economic ties between the government and the media are relationships that have been in place since the beginning of the reporting era in Malaysia. One of the initial efforts to transfer media ownership from the government to the private sector was to privatize Sistem Television Malaysia Berhad (STMB) or better known as TV3. TV3 received its license in 1983. Fleet Group which was UMNO's holding company held 40 per cent of stock, making it the only single entity that had control over the station and that also gave them the right to select the remaining ownership partners. TV3 in turn owned MEGA-TV (now a defunct sister company) and Multichannel Multipoint Distribution Service (MMDS formally known as Business Radio Service (BRS)) or Wireless Cable, a cable provider that came in tandem with the deal. 
In 1994 a television broadcast license was issued to Melewar Corporation and Utusan Melayu (M) Berhad to operate Metrovision. Tunku Panglima Besar Tunku Tan Sri Abdullah ibni Tuanku Abdul Rahman was Melewar's Industrial Group Chairman at the time. Five years into operations, Metrovision was struggling and was 'temporarily' off-air by 1 November the same year (1999). In 2002, the Ministry of Finance owned 30 per cent of the consortium that operated Mega TV while a subsidiary firm, Sri Utara, an investment arm of the Malaysian Indian Congress (MIC), a political party in the coalition government, owned another 5 per cent of Mega TV (Lee, 2001). They resumed broadcasting on Thursday 1 January 2004 as 8TV after being bought by Media Prima Berhad.

All political parties in the coalition government and their investment companies have also interest and control in the major mainstream newspapers in Malaysia. When TV3 was issued the country's first and only private television broadcasting license in 1983, their major shareholders then included the Fleet Group, UMNO's (UMNO is the main ruling political party headed by the Prime Minister) holding company, the UMNO-controlled Utusan newspaper publishing group, MIC's Maika Holdings, Daim Zainuddin (Minister of Finance then), and the now bankrupt Syed Kechik group.

Fleet Group and later Renong, took control over the then Daim-controlled New Straits Times group. In 1993 a management buy-out through the Malaysian Resources Corporation Berhad (MRCB) took over of the then lucrative TV3 from the other main minority shareholders. This was done with considerable help from the Hong Leong group's Quek Leng Chan which then placed both TV3 and the NST group firmly in the camp of Finance Minister Anwar Ibrahim at the time. He in turn effectively deployed it to become UMNO's Deputy President and Deputy Prime Minister (Gomez, 2004).

Media Prima Berhad, which now owns TV3 and several TV stations under its wing, is a company listed on the Main Board of Bursa Malaysia and is the leader in Malaysia's integrated media investment group. It currently owns 100 per cent equity interest in TV3, 8TV, NTV7 and TV9. In addition, Media Prima now (as of 2013) owns more than 98 per cent equity interest in The New Straits Times Press (Malaysia) (NSTP) Berhad, one of Malaysia's largest publisher which prints the New Straits Times, Berita Harian and Harian Metro, three highest circulated national newspapers. It also owns three radio networks, Fly FM, Hot FM and One FM (Media Prima Berhad, 2010).

\section{Literature Review}

Henningsen \& Henningsen (2007) defined two features of the decision making process. Although the decision making process was not done in the newsroom per se, the researchers came up with two important factors. First, group members should recognize that the information is missing. That is to say, group members should be able to identify certain items of decision-relevant information that were unavailable to them. Second, missing information should 
carry no weight in the final decision. Ignoring information indicates that groups choose to make a decision using a diminished information set.

Faridah (1995), quoting Simon (cited in Dimmick \& Coit 1982) on the same aspect argues that organizations can never be perfectly rational because their members have a limited capacity to obtain and process information. In her findings, it is clear that firstly, the management makes decisions in the newsroom while the second, the management consults journalists but makes the final decision nevertheless. The ideal state according to the researcher is where the journalist has greater autonomy in decision making but this rarely happens in the Malaysian newsroom scenario. However, decisions regarding the length of the story, news suggestions, editing and rewriting the news, postponing a story, visual suggestions and long range news plans involve some consultations by management with the journalists, even though the final say are in the hands of the management.

Given that the newsrooms often work on daily schedules, decision making is a vital skill. However, the very routine that demands sound decision making also hinders development of that skill. Overby (1995) observes that newsroom personnel often lack time to think and discuss basic decisions; the impetus to deliver news decreases the chances for pertinent thought and dialogue. For the most part, communication scholars have taken a macroeconomic approach to decision making effects. They generally view such effects as a static entity that can be packaged and plugged into any theoretical construct and measured and described via discussion of market structure alone. Heretofore, scholars have largely ignored the organizational context of newspapers, despite the widely acknowledged notion that there are direct, organizational, social and cultural causes of media content as well (Shoemaker and Reese, 1996). In short, decision making requires additional perspectives. A greater understanding of the process by which editors make decisions, needs to and is about the ownership and how it effects the decision making process of the newsrooms. Napoli and Zhaoxu (2007), takes stock of this issue in their research when they examine the relationship between television station ownership characteristics and local news and public affairs programming through an expanded analysis of data from the Federal Communications Commission (FCC's) study of Big Four broadcast network affiliates. The results indicate that the FCC's conclusion is that network-owned and operated stations provide more local news and public affairs programming than other affiliates, and that stations with newspaper holdings provide more local news and public affairs programming than stations without newspaper holdings up only when these two program types are analyzed in combination. When these two program types are analyzed independently and when additional explanatory factors are taken into consideration, these ownership characteristics are positively related to news programming, but not to public affairs programming. The researcher's findings reveal that while financial resources and competition provided stations with greater incentives to produce local news programming, several factors related to station ownership did not. In terms of the quantity of local news provided, once the decision to provide any news was reached, none of the 
ownership variables were positively related to the quantity of news programming provided.

Locally, Zaharom and Mustafa (1998) in their research on ownership and control of the Malaysian media discusses the history of the mainstream press and broadcasting in Malaysia which has been one stringent political, legal and more recently, economic controlled. From the emergence of the first newspaper, The Prince of Wales Gazette, in 1806, the introduction of state-run television, TV1 in 1963, the emergence of commercial television, TV3 in 1984, and the launching of Malaysia's first broadcast satellite, Measat 1, in 1996, the state's role in the overall scheme of things has been central.

In a more recent study on the public (TV1) and private pay television (Astro Awani) (Roslina and Faridah, 2012), the researchers also found that while RTM has different influences in terms of decision making, as from supra-organizational (ownership dictates content) to industry level of interorganization relations (competing organizations) to societal influences (government influences), Astro Awani has one additional influence, which is community or market influence (advertising). As RTM sees itself as an information provider or mouth piece to the rakyat (the people), advertising although important would not be the top priority. Astro Awani on the other hand, is just the opposite since advertising contributes a substantial amount to the prolonged livelihood of this organization.

Theories of story selection for Astro Awani is very much journalistic centered as the structure is bottom up and very dynamic. The other theories such as event centered and technological determinants play a major role in the news outfit as the news is well integrated with the social network entity via Facebook and Twitter. The news is also shared between different channels in the organization, radio included. RTM still follows the standard regiment of routine centered news line-up (local, business, foreign, sports). On certain occasions, event centered news also takes precedent depending on news worthiness.

\section{Methodology and Data Collection}

Data for this research was derived from in-depth interviews with the respective key personnel from both organizations under study. The identities of the informants are kept confidential, and they will be referred to as alphabetical informants only. Four informants were interviewed from News \& Current Affairs Radio \& Television Networks, Media Prima Berhad namely Informant A, Informant B, Informant C and Informant D. While from TV1, Informant I, Informant J, Informant $\mathrm{K}$ and Informant $\mathrm{L}$.

When developing the purposive sampling for this research, it was important to look at and understand the hierarchy of the newsrooms under study. The organization structure for each and every organization was difficult to secure as the organization structures are high security priority. Based on the 
basic structure in the newsrooms, purposive samples were selected to fulfill the research needs of this study.

For this research, data collection was done through in-depth interviews or semi structured interviews with chief news editors of the main newsrooms in TV1 and TV3. The justification for this is because with every time Prime Ministers change, CEO's or COO's or General Managers of the newsrooms also change, get transferred or given the golden hand-shake to leave. The ones that have remained through the storms of change have been the Chief Editors.

In-depth interviews focused on the questions that would provide information on the topic of research and were guided by the decision making process from the editors point of view from both media power houses factoring in government policies. The main reason is to identify the stages of decisionmaking in the production of news and how they have been affected by the policies introduced by the Prime Minister. From the main questions formed, supplementary questions were asked in order to get more information to complete this study.

The in-depth interviews are based on three research questions:

- Research Question 1: Who makes decisions at different levels of production - pre-production, production and post-production in the making of news?

- Research Question 2: What forces (internal/external) have influenced the decision making process in the newsrooms of the broadcasting system?

- Research Question 3: What government policies influenced the network's programming.

The data from the in-depth interviews were coded for topics on decision making, frequency of topics and examples based on real events in the newsroom. The discussion covered a range of topics ranging from experience and pre-production, production and post-production decision making.

\section{Data Findings}

\section{Decisions in Different Stages of News Production}

Both media organizations work differently in terms of the decision making process at different stages of production. The Group Managing Editor, Group Deputy Managing Editor, Head of News, Chief News Editor, Editors and Subeditors at TV3 determined the first round of selection for the news in terms of local, regional and international. TV3 has an edge since they have regional offices everywhere so there would be an abundance of news to cover their main Buletin Pagi (morning bulletin) at 7 am (30 minutes), Buletin 1.30 (1.30 bulletin - 30 minutes) and their main newsreel Buletin Utama (main bulletin 1 hour) for the Malay news at 8 pm (1 hour) and Nightline for the English News at midnight (30 minutes). This is interspersed with Berita Terkini (news 
updates) at $10 \mathrm{am}, 11 \mathrm{am}, 12$ noon, $4 \mathrm{pm}$ with the $5.30 \mathrm{pm}$ slot dedicated to Business News. During the weekend there's a sight change in Berita Terkini with the news aired at $11 \mathrm{am}, 12$ noon, $4 \mathrm{pm}$ and $6 \mathrm{pm}$. The duration of Berita Terkini is 10-15 minutes depending on stories highlighted. For the news lineup, decisions are made collectively as a group and the most important stage is the pre-production.

TV1 also has the same set-up similar to TV3 where they have regional offices everywhere or better known as Biro's but on a bigger scale. This is also to facilitate news to cover their every hour bulletins from 9 am to $1 \mathrm{pm}, 3 \mathrm{pm}$, $5 \mathrm{pm}, 8 \mathrm{pm}, 10 \mathrm{pm}, 11 \mathrm{pm}$ and $12.30 \mathrm{am}$. Likewise, the decision making process for the news line-up, is also done collectively as a group and deem the same stages as important which is the pre-production stage.

\section{Factors that Affect the News Decision-Making Process}

Forces that influence the decision making process in the broadcasting system are numerous. There are several factors that have been identified that influences the decision making process in the newsroom in the broadcasting system for these two stations. These factors can be further broken into internal and external factors.

\section{$\underline{\text { Internal Factors in TV3 }}$}

\section{Staff Performances}

Staff performance could be looked at something minor if the company is young but after 28 years being in the business, there is the need to be better and stronger in terms of presentation and production. "After 28 years of being in operation, there shouldn't be mistakes especially minor ones like wrong graphics, wrong spelling of names (during supering), readers that still make mistakes when reading or coughing while the vt (footages) are rolling). They need to take ownership and responsibility for their job" (Informant D). (Also refer to Table 1 Summary of In-Depth Interviews Results). 
Table 1. Summary of In-Depth Interviews Results

\begin{tabular}{|c|c|c|c|}
\hline & $\begin{array}{l}\text { RQ } 1 \text { Who makes } \\
\text { decisions at } \\
\text { different levels of } \\
\text { production - } \\
\text { preproduction, } \\
\text { production and } \\
\text { post-production in } \\
\text { the making of } \\
\text { news? }\end{array}$ & $\begin{array}{l}\text { RQ } 2 \text { What forces } \\
\text { (internal / external) } \\
\text { have influenced the } \\
\text { decision making } \\
\text { process in the } \\
\text { newsrooms of the } \\
\text { broadcasting } \\
\text { system? }\end{array}$ & $\begin{array}{c}\text { RQ } 3 \text { What } \\
\text { government } \\
\text { policies influenced } \\
\text { the network's } \\
\text { programming? }\end{array}$ \\
\hline Informant A & $\begin{array}{l}\text { Decisions are made } \\
\text { collectively, twice } \\
\text { daily. Once in the } \\
\text { morning meeting at } \\
10 \text { am and } 6 \text { pm to } \\
\text { determine the } \\
\text { headlines. }\end{array}$ & $\begin{array}{c}\text { Internal: } \\
\text { Self-censorship } \\
\text { Company's KPIs } \\
\text { External: } \\
\text { Government } \\
\text { guidelines } \\
\text { Advertisement } \\
\text { Ratings } \\
\text { Complaints and } \\
\text { legal action } \\
\end{array}$ & $\begin{array}{c}\text { Economic } \\
\text { transformation } \\
\text { program, political } \\
\text { transformation } \\
\text { program } \\
\text { Government, } \\
\text { transformation } \\
\text { program, } \\
\text { everything }\end{array}$ \\
\hline Informant B & $\begin{array}{l}\text { Decisions are made } \\
\text { collectively, twice } \\
\text { daily. Once in the } \\
\text { morning meeting at } \\
10 \text { am and } 6 \text { pm to } \\
\text { determine the } \\
\text { headlines. If } \\
\text { Informant A is not } \\
\text { around then } \\
\text { Informant B will } \\
\text { chair the meetings. }\end{array}$ & $\begin{array}{c}\text { Internal: } \\
\text { Self-censorship } \\
\text { Company's KPIs } \\
\text { External: } \\
\text { Government } \\
\text { guidelines } \\
\text { Advertisement } \\
\text { Ratings } \\
\text { Complaints and } \\
\text { legal action }\end{array}$ & $\begin{array}{l}\text { All policies, as and } \\
\text { when it happens }\end{array}$ \\
\hline Informant C & $\begin{array}{l}\text { Decisions are made } \\
\text { collectively, twice } \\
\text { daily. Once in the } \\
\text { morning meeting at } \\
10 \text { am and } 6 \text { pm to } \\
\text { determine the } \\
\text { headlines. }\end{array}$ & $\begin{array}{c}\text { Internal: } \\
\text { Self-censorship } \\
\text { Company's KPIs } \\
\text { External: } \\
\text { Government } \\
\text { guidelines } \\
\text { Advertisement } \\
\text { Ratings }\end{array}$ & $\begin{array}{c}\text { Economic } \\
\text { transformation } \\
\text { program, political } \\
\text { transformation } \\
\text { program } \\
\text { Government, } \\
\text { transformation } \\
\text { program, } \\
\text { everything }\end{array}$ \\
\hline Informant D & $\begin{array}{l}\text { Decisions are made } \\
\text { collectively, twice } \\
\text { daily. Once in the } \\
\text { morning meeting at } \\
10 \text { am and } 6 \text { pm to } \\
\text { determine the } \\
\text { headlines. }\end{array}$ & $\begin{array}{c}\text { Internal: } \\
\text { Staff performance } \\
\text { Self-censorship } \\
\text { Company's KPIs } \\
\text { External: } \\
\text { Advertisement } \\
\text { Ratings }\end{array}$ & $\begin{array}{l}\text { All policies, as and } \\
\text { when it happens }\end{array}$ \\
\hline
\end{tabular}




\begin{tabular}{|c|c|c|c|}
\hline Informant I & $\begin{array}{l}\text { Decisions are made } \\
\text { collectively, twice } \\
\text { daily. Once in the } \\
\text { morning meeting at } \\
9 \text { am and } 5 \text { pm to } \\
\text { determine the } \\
\text { headlines. Meetings } \\
\text { are chaired by } \\
\text { Informant J. }\end{array}$ & $\begin{array}{c}\text { Internal: } \\
\text { Inexperienced and } \\
\text { new staff } \\
\text { External: } \\
\text { Government } \\
\text { stakeholders } \\
\text { Advertisements }\end{array}$ & $\begin{array}{c}\text { 1Malaysia, } \\
\text { Economic } \\
\text { transformation } \\
\text { program, political } \\
\text { transformation } \\
\text { program, } \\
\text { PEMANDU } \\
\text { projects, NKRA } \\
\text { Government } \\
\text { transformation } \\
\text { program. }\end{array}$ \\
\hline Informant $\mathbf{J}$ & $\begin{array}{l}\text { Decisions are } \\
\text { made collectively, } \\
\text { twice daily. Once } \\
\text { in the morning } \\
\text { meeting at } 9 \text { am } \\
\text { and } 5 \text { pm to } \\
\text { determine } \\
\text { headlines. } \\
\text { Meetings } \\
\text { chaired are } \\
\text { Informant J. }\end{array}$ & $\begin{array}{l}\text { Internal: } \\
\text { Inexperienced and } \\
\text { new staff } \\
\text { External: } \\
\text { Government } \\
\text { stakeholders }\end{array}$ & $\begin{array}{l}\text { 1Malaysia, } \\
\text { Economic } \\
\text { transformation } \\
\text { program, political } \\
\text { transformation } \\
\text { program, } \\
\text { PEMANDU } \\
\text { projects, NKRA } \\
\text { Government } \\
\text { transformation } \\
\text { program. }\end{array}$ \\
\hline Informant $\mathrm{K}$ & $\begin{array}{l}\text { Decisions are } \\
\text { made collectively, } \\
\text { twice daily. Once } \\
\text { in the morning } \\
\text { meeting at } 9 \text { am } \\
\text { and } 5 \text { pm to } \\
\text { determine } \\
\text { headlines. } \\
\text { Meetings } \\
\text { chaired are } \\
\text { Informant } \mathrm{J} \text {. }\end{array}$ & $\begin{array}{l}\text { Internal: } \\
\text { Inexperienced and } \\
\text { new staff } \\
\text { Minister's } \\
\text { interference } \\
\text { External: } \\
\text { Bernama stories } \\
\text { Government } \\
\text { stakeholders }\end{array}$ & $\begin{array}{l}\text { 1Malaysia, } \\
\text { Economic } \\
\text { transformation } \\
\text { program, political } \\
\text { transformation } \\
\text { program, } \\
\text { PEMANDU } \\
\text { projects, NKRA } \\
\text { Government } \\
\text { transformation } \\
\text { program. }\end{array}$ \\
\hline Informant L & $\begin{array}{l}\text { Decisions are } \\
\text { made collectively, } \\
\text { twice daily. Once } \\
\text { in the morning } \\
\text { meeting at } 9 \text { am } \\
\text { and } 5 \text { pm to } \\
\text { determine the } \\
\text { headlines. } \\
\text { Meetings } \\
\text { chaired are } \\
\text { Informant } \mathrm{J} \text {. by }\end{array}$ & $\begin{array}{l}\text { Internal: } \\
\text { Inexperienced and } \\
\text { new staff } \\
\text { Minister's } \\
\text { interference } \\
\text { External: } \\
\text { Bernama stories } \\
\text { Government } \\
\text { stakeholders }\end{array}$ & $\begin{array}{l}\text { 1Malaysia, } \\
\text { Economic } \\
\text { transformation } \\
\text { program, political } \\
\text { transformation } \\
\text { program, } \\
\text { PEMANDU } \\
\text { projects, NKRA } \\
\text { Government } \\
\text { transformation } \\
\text { program. }\end{array}$ \\
\hline
\end{tabular}




\section{Self-censorship}

Self-censorship has always been practiced in TV3. This would generally cover sensitive issues like religion, race and multicultural sensitivity. "Of course we believe in self-censorship. Self-censorship means that we know what we are doing and what we cannot do. We brief our reporters, producers and editors (so everybody is on the same page). It is company policy" (Informant A). (Also refer to Table 1).

\section{Company's KPIS}

The company's KPIs and the newsroom's KPIs in terms of revenue also need to be factored into the news process and the overall makeup of the line-up of the news as it will impact other external factors such as ratings and advertisements. "We have to balance up or we will be in a dilemma. Of course we have our KPI's and they include the editorial part, which is editorial content and everything else because it is not only about quantity but quality news" (Informant A). (Also refer to Table 1).

\section{External Factors in TV3}

\section{Guidelines from the Government}

Although this situation doesn't happen often but it is highlighted as one of the internal factors that causes stress and affects the process of the news decision making process. According to Informant A, they support the government of the day, so their stories are generated accordingly. But this is not done without "some political affects" according to Informant B. As journalists they see it as positive morale. Informant B thinks that the Najib's administration understands that fact. Informant $\mathrm{D}$ has a different perspective about the changing Chief Editor that accompanies every Prime Minister. This is what he had to say: "There will changes with every new PM, there always seems to be the need to prove ourselves every time. It can sometimes be stressful and tiring".

\section{Advertisements}

Advertisements are also another factor that effects the duration of the news line up but not so much of the news decision making process per se. Informant $\mathrm{A}$ and $\mathrm{C}$ agree that it is a constraint which cuts the news to 45 minutes from the hour allocated. The advertorial and the advertisements limit the airtime, "giving us hard news something like 30-40\%".

\section{$\underline{\text { Ratings }}$}

Ratings are also an important factor in the broadcasting business. The higher the ratings, the better the chances for the programme being 'sold'. It also helps to determine the 'rates' of a certain band. If a programme's ratings fall, there will also be consequences towards the selling power. According to Informant B, "there is a fluctuation. If it is the school holidays, everybody goes on holiday then that's a problem (because no one is watching the news)". 
The rating system is accumulative, which means that it doesn't depend on one bulletin only but is an average of seven days. A.C. Nielsen accumulates, and averages it out, (so it is a weekly ratings and not just one transmission) (Informant A). (Also refer to Table 1).

\section{Complaints \& Legal Action}

Viewers complaints and legal action, although seems to be the playground of the newsroom. it's not something that is 'fun' to indulge in as it takes up many man hours, court presence and legal fees. Informant A agrees that "sometime we overlook things like deadlines. Deadlines can sometimes hog our production. At times deadlines also dampen the process in terms of production because when the stories come in late and it's a big story, you need to process the story fast. Sometimes when it goes to graphics or to the different production stages, there are some glitches; they're bound to make mistakes like spelling, wrong graphics or wrong pictures. This is not a major concern but of course one of those".

\section{Internal Factors in TV1}

Similar to TV3, the decision making process in TV1 is also an ongoing process till the news goes on the air. These decisions will be determined based on the issue at hand or updates or new developments.

The first round of decision making in the newsroom is done by the subeditors. The sub-editors "will receive the news from the reporters, then they will decide how the introductions to the stories would be. Sometimes our reporters do not write based on the inverted pyramid but the opposite so it is up to the sub-editors to edit the news." (Informant K). (Also refer to Table 1).Therefore "the first level of decision making happens at the sub-editors level to look at news of the day" (Informant L) (Also refer to Table1)..

If the staff is a more senior reporter that knows the tricks of the trade then the editors and sub-editors would trust them with the stories, even Prime Minister's stories. But if the reporters are still new, they need to be guided appropriately.

According to Informant $\mathrm{K}$, "sometimes when they come back from an assignment, there are many angles. When PM announces something, it's not only a single issue but several issues, so we will ask the reporter to highlight what we deem as important. That's how we guide the reporters because sometime they will bring back a bigger story or a smaller story form what we have planned in the line-up. So they have to come back and tell us what they have."

\section{Inexperience and New Staff}

The newsroom at RTM is understaffed as they need to cater for the hourly news bulletins, there are many new staffs that have been employed from Universiti Teknologi Mara (UiTM) and from reality shows that are very new to the broadcasting world, hence a lot of guidance is needed. Under deadline 
pressures, some of these stories have to be re-written and re-edited that sometimes do not meet the specific deadlines for the news.

In terms of manpower, RTM has a strong of 18 editors, 7 sub-editors and 60 reporters to cater for the four different desks (Malay, English, Mandarin and Tamil). Even that is not enough according to the Editors that I spoke to as they need to cater for the many news bulletin on a daily basis, hence they also taken staff on a contract basis to fulfill the manpower need.

"We clearly have a staff shortage problem. We have no choice but to take staff on a contract basis because there is much news to process hourly. We're working non-stop. For me, I start work at 8.30 am and at $8.30 \mathrm{pm}$, I'm still here. It's so difficult to get good staff especially at this time when the elections are drawing near. It is so difficult to get people that you don't have to train. Very difficult" (Informant K) (Also refer to Table1).

Informant $\mathrm{L}$ also reiterates the same issue. Not only are they new and inexperienced, they also lack the understanding of sensitive issues like race and religion.

\section{Minister's Interference}

Although this is not the current situation but this was highlighted as one of the internal factors that causes stress and affects the process of the news decision making. The information minister in question was Datuk Seri Zainuddin Maidin $\left(17^{\text {th }}\right.$ February $2006-8^{\text {th }}$ March 2008). During his reign "it was different because he was a newsman himself, so he knew everything and he wanted to be close to the newsroom operations. But he always interfered. He always wanted to be directly involved and he kept in touch with us constantly. Because news is fast, he always inquired whether we had all our materials on time because he was a newsman. That's the biggest difference (Informant L). Informant K reiterates that, "it was very stressful."

\section{External Factors in TV1}

\section{BERNAMA Stories}

BERNAMA is a government news agency that provides news stories for all broadcast, print and online news agencies. Reporters are known to check with BERNAMA stories in order for the introduction of the news to be, at least in tandem with the mainstream news stories. BERNAMA has been known throughout the years to be 'efficient' in terms of churning out the news. Of late that does not seem the case.

"The BERNAMA stories are sometimes not update. We are very disappointed that the stories are late. They give the stories to Utusan, Berita Harian and every news organizations, we're always the last. So we don't depend on them so much." (Informant J) (Also refer to Table 1).

\section{Government as Stakeholders}

As the government is the main stakeholder for RTM, it's not surprising that the coverage of news has a slant towards that although according to the editors, there are no directives received at their level. Most decisions are done 
at their level with the 'okay' from the Deputy Director of News and Current Affairs.

However, sometimes there will be 'advice' from the management if the stories are sensitive issues. "If we feel we can re-angle the story then we will, but if we cannot because the story is straight forward then we would drop the story based on 'advice"' (Informant I) (Also refer to Table1).

\section{$\underline{\text { Advertisements }}$}

Advertisements are also another factor that effects the duration of the news line up but not so much of the news decision making process per se as making money is not the main priority at RTM. But there are exceptions to this rule. "Let's say one company has bought air time for 10 minutes during the Olympic Reports in the sports section and they also want to promote their product. So we have to follow and allow for the 10 minute duration, that's the decision." (Informant I).

\section{Data Findings: Practices, Pegs and Proxies}

Practices - Decision Making and the Gatekeeper's Mission

When analyzing the various responses to the reasons on how these two news organizations derived on the decision making process, these are the three themes that emerged. The decision making process in the Malaysian newsrooms could be unique to this country but they are also characteristics to other newsrooms studies done worldwide (Gans, 1980, Joseph, 1983, Lowrey and Chang, 2010) and in the local vicinity (Faridah, 1995, Khattab, 2004 and Faridah et al, 2012). The assumption is that it is traditional practice within the media organization that most editorial and other newsroom decisions lie in the hands of the management and this is proven to be true.

It doesn't really matter where the research is done, whether newsrooms in China, Russia, Singapore, Hong Kong, Zimbabwe, the US, Philippines or even in Malaysia, the 'authoritative sources' are also the power structure and the privileged elites who feed it. It is also accurate to say that the mainstream media refers and defers to them as they influence the way news is reported, interpreted and decided what will go un-reported or not followed up (Pereira, 2008).

A few matters come to point in this study. The reporter and the editor's personal and professional news judgement, organizational news-gathering routines that establish the working relations between reporters and their bosses, the economic constraints on news production, the flow of information, communication technologies and most importantly the ideological factors that define the limits of time and space in news gathering. Research by Lippmann (in Hachten 2005: xiii) and Bennett (2007) also confirm this notion.

It is correspondingly accurate with what Gans (1980) reiterates as how considerations in decision making are done. In these Malaysian newsrooms, these elements are division of power and labor of news staff decreases according to lessening of rank and power. On the top levels are the policy makers, followed by top editors (or producers in broadcasting), section heads 
and reporters and these are the important gatekeepers that make decisions on a day to day basis.

News format and presentation is the final stage in the presentation of news which exerts ultimate control over the product in all news organizations. Producers view and review stories, instruct editors and reporters on how to construct, 'play' and narrate the news. If editing fails to conform to organizational values, the producer or editor can 'kill' the story with ease but with justifications.

Organizational rules and editorial policies are also taken into consideration to coordinate the efforts of individual journalist, editors, and producers into a news product that meets a certain standard and preset schedule. The guided rules act as guidelines for editors and reporters in filtering and evaluating information and making decisions in these media organizations. Personal set of news values, interests, needs, biases likewise play a part in determining the news lineup (Gans, 1980, Berkowitz, 1997, Faridah, 1995, Green, 1999, Johnson, 2004, Faridah et al. 2011 and Faridah et al, 2012).

The adage of editorial independence therefore is non-existent as found in this study as there are underlying issues between editors and their superiors, sideways (between departments) and downwards (with reporters acceptance or otherwise of editorial change). Notwithstanding these news organizations continue to pursue the aim of objectivity in news reporting - of disinterested, unbiased and factual reporting of the news (Green, 1999).

Findings of this research similarly indicate that the editor controls not only news topics but also the number of news items; editors as well as top management do have their own prejudices and favorites in terms of news items due to guidelines imposed. The most important characteristic of news is 'consequence' (importance) to the news consumer and the news people try to be balanced, which means that they do not want to be influenced by individual prejudices since their professional norms, including journalistic objectivity, prevent news selection from being affected by their own subjective news values as echoed by Gutierrez et al. (1995) and Faridah et al. 2012.

\section{Pegs - Broadcast Governance and Regulation}

It is clear that TV1 follows the government model in which public broadcasting is controlled directly by the government or by the political majority. This system is similarly practiced in France, Western Europe, Greece, Portugal and Spain. TV3, on the other hand uses the professional model as epitomized by the British Broadcasting Corporation (BBC), where a strong tradition has developed that broadcasting should be largely insulated from political control and run by broadcasting professionals. This model is also characteristic of the Canadian Broadcasting Corporation (CBC), Irish Public Broadcasting, a few Scandinavian countries and public broadcasting in the United States (Hallin and Mancini, 2011).

Past researchers (Mustaffa, 2000, Netto, 2002, Khattab, 2004, Lacy et. al., 2004 and Ramanathan, 2008), have derived conclusions for research done locally and internationally and at different times that the political motivated 
media curbs have denied the Malaysian public their right to a full range of viewpoints. This is not entirely true for this study as TV1, although being a government television station, reports news as is, bias towards the government, no doubt but still reports news directly.

TV3 on the other hand, uses the professional model but operates differently as the study suggest. TV3 is more stringent in terms of their decision making process because of the guidelines and the presence of the Putrajaya Appointee, that has a hand in the decision making process.

Although in many previous research by Zaharom and Mustafa (1998) and Yesudhasan and Wong (2010) state that the ruling government has a list of laws at its disposal namely - the Printing Presses and Publications Act, the Broadcasting Act, the Control of Imported Publications Act, the Internal Security Act, the Official Secrets Act, the Sedition Act and Defamation Act just to name a few - said to reinforce economic control and also on the media. The latest development was the abolishment of the Internal Security Act.

The Malaysian media to a certain extent is pressured by the structure and the people who make up the structure, to be biased and virtually silent on issues critical of the government and those deemed sensitive to the general public, especially on issues concerning race and religion. With all this going on in the media industry in Malaysia and people who assume the on goings in the newsroom, it is not surprising then it is ranked amongst the most stringent in the world. The key to this dominance is the legislative restrictions mention combined with corporate and beaucratic control by government parties and ownerships (Yesudhasan and Wong, 2010).

One piece of good news however, starting $15^{\text {th }}$ July 2012, the press and broadcasting licenses will not need to be renewed to stay in operations. When the editors were asked of this, they didn't seem to be affected very much. Work is "business as usual" (Informant A \& C) because that is how they have been operating. Revoking the license does not mean that they can say bad things about the ruling government. The consensus at these organizations is simply "respect for the government of the day." (Informant E, F \& G) (Also refer to Table 1).

Based on the research, it is clear that a lot of deliberations take place in these newsrooms of power broadcasting houses especially for what they term as 'big stories'. These could range from political, economy, events or even sports. But on some occasions, a few editors also do judgments based on what they describe as 'feel' or 'news sense' (Gans, 1980 and Shultz, 2007).

\section{Proxies - Ownership Links}

The results of these in-depth interviews also agree with Zaharom and Mustafa (1998) that by and large the Malaysian mainstream media act as government mouthpieces because of ownership issues. But the difference is some of them do not have a choice. But the ones that do have a choice, they see themselves as partners with the government in tandem with nation building.

Saying that critical reports with the multi-layered nature of controls on the day-to-day basis at the operational level of news production that invariably 
prevent such reports from seeing the light of day is not entirely true. There are many ways for a certain issue to be discussed. The approach taken by Awani (the pay tv) seems to work nicely. Having a 360 degree tactic gives more than one side of an issue but more importantly it rather looks at issues that affect people the most so the government has no choice but to listen, and they do.

As oppose to Papandrea's (2006) research that only discusses issues of plurality and the diversity of views, media markets and the effects of the ownership controls, this study dwells further into how it effects the organization and the news content. While the news at TV1 is pretty straight forward, the public feels that the news from TV3 is slanted towards the government and this causes disaffection among some of the viewers. There is even a Facebook group called 'Kami Boikot Bulletin Utama TV3' (We boycott the TV3 news bulletin). This might be one of the reasons for the fall in ratings (2.4 -2.5 million) besides the reason of too many advertisements that breaks the news momentum.

While Schudson (2002) finds it hard to determine the link between ownership of news organizations and the character of news coverage, for these news organization it is clear what the news treatment is like although the focus for this research was only the ten new policies under the current Prime Minister. No doubt as Schudson highlighted, it is a mix and blend of a commercial system while serving the growing interest of the public.

These broadcasting houses also actively produce current affairs programmes that are issues picked up from the news bulletin itself. These initiatives are identical to the findings of Napoli and Zhaoxu (2007).

So in a nutshell, transformation in the newsrooms is inevitable and demands agility, adaptability and efficiency from communication professionals. TV3's and TV1 stakeholders are clear cut and there has been much change in terms of decision making and news presentation with the change of Prime Ministers, especially in TV3. Nevertheless having said that, Informant $\mathrm{B}$ feels that the powers that be "do not micro-manage the newsroom".

In general, as reported in several newsroom studies internationally by Gans (1980); Joseph (1983); Gaziano and Coulson (1988) and locally by Liew (in Faridah 2001 ; 1990) ; Faridah (1995), Faridah (2011) and Faridah et al. (2012), it is a traditional practice within the media organizations that most editorial and other decisions lie in the hands of the management. And when the management's hands are tied by the policies that camouflage the practices, pegs and proxies, which in turn dictate the decision making process in the newsrooms, it becomes less democratic. Most often than not, not adhering to these 'guidelines' would mean treading on thin ice. 


\section{Theories of Story selection in Newsrooms}

\section{TV3}

Although the news line-up looks typical of a routine centered story selection on a daily basis (local, business, foreign, sports, closing), but according to Informant B "if there is a big earthquake somewhere, the foreign news will pick up as news of the day" and then for that particular day it turns into event centered. Event centered news would mean breaking news for example earthquakes, major accidents, sports and outstanding achievements, just to name a few.

Given the technology that they have, for example the OB (Outdoor Broadcasting) trucks/vans, studios, links and manpower that covers the ground crew, technical producers, location producers and host or reporter on location, technological determinants are not a hindrance for production. The newsroom can manage a few crossovers a week when the assignments are big, notwithstanding the overseas assignments.

In terms of economic determinants, the story which molds the national economy that carries a lot of weight and given prominence for almost the whole bulletin is of course the budget. When the Prime Minister delivers his budget speech, then the first and second block of the news bulletin will carry budget stories.

Ideological determinants also play a role in the news as it is the belief that journalists align the news to the political ideology of those holding power in the country. So far this is in tandem with the government of the day.

External centered happens when groups in society are powerful enough to create what they call 'public events' and to gain access to journalists and a very good example would be the 'Bersih' rallies. Reporters and cameramen go on the ground to cover these events to report and see for themselves what is happening. But on more than one occasion, they have been denied access because they are termed as mainstream. The opposition leaders often talk about "freedom of the press and yet at times they don't let us cover, that is another problem. No Utusan, no TV3, I mean you're talking about freedom of the press and yet you fault us from coming to your function" (Informant A) (Also refer to Table 1).

TV3 is not so much journalistic based unless they are senior reporters that are capable of delivering their own stories without much hassle and monitoring. Normally these are special reports on ongoing issues.

TV 1

TV3, like TV1 also follow a routine based news bulletin starting with general news, economy, foreign and sports. So if a "sports event dominates the news" then, it will be event centered for the day. The same goes for "economic stories like the tabling of the budget" (Informant J) (Also refer to Table 1). On occasion, 'human interest stories (for example peculiar weddings) also play a part in the general news just to break the monotony of the heavy news or can just be used as the closing" (Informant K) (Also refer to Table 1). TV1 also 
has a weather segment called 'Infocuaca' as part of social obligation to the public.

In terms of the other determinants - technological, economic and ideological are almost the same as TV3. The budget story was the same example that was given in the course of the interview to all Informants and they agree holistically that that would be the obvious economic determinants. In terms of ideological determinates, it goes without saying as TV1 is government owned, therefore everybody and anybody tows the line with the government of the day.

TV1 tries to take on new perspectives by inviting opposition leaders for their talk shows and according to Informant I, they have a pretty balanced make of guests for their talk shows but sometimes the discussion becomes heated as the subject matter is sensitive to begin with, for example the Lynas issue. So when topics discussed are sensitive, they take precautions to record the programme rather than to transmit it live (Informant I) (Also refer to Table 1). These external factors are not external centered for the news per se but are derived from the issues picked up from the news.

TV1 is not journalist centered for obvious reasons as many of the staff are new, not experienced and many of them do not have the proper background in terms of academia as some of them were taken from reality shows (Informant $\mathrm{K}$ ) (Also refer to Table 1). So it is understandable why it is not journalistic centered.

\section{Prominence of Government Policies}

Overall view for both stations is to cover the ten policies that were launched by the Prime Minister when he held office. Events on the policies are covered as it happens and sometimes when Najib announces achievements that have been accomplished on TV1. All television stations will also transmit the announcement via "Ehsan RTM" an understanding that the feed is free of charge.

The Economic Transformation Programme is a policy that has been frequently highlighted in the TV3 news. "Never before have we reported so many stories on government policies - the ETP, the political transformation program, the government transformation program, everything" (Informant A \& B) (Also refer to Table 1).

Generally, during the in-depth interviews, Informants from TV3 and Informants from TV1 agree that they cover all policies by the Prime Minister as and when it happens. Nonetheless, when asked for examples, (i) becoming a viable government (ii) becoming a developed nation, (viii) 1Malaysia and (v) spurring economic stability (the GTP and the ETP) surfaced as examples.

The last three policies namely (vii) independence and national integration, (ix) Malaysia and ASEAN and (x) Malaysia and international issues were not raised in neither the in-depth interviews nor the newspapers. During the duration of the study there were no stories pertaining to these issues. 


\section{Conclusion}

Data from this study suggest the news selection decisions were based on several considerations in addition to news value. News content is built from information that is easy to explain, that would provide a good audience draw (ratings) and that could be assembled with efficiency of effort (the three stages of production - pre-production, production and post-production). News people also rely on their gut feelings or instincts to what makes a good newscast. What are important in terms of decision making framework in specific terms are interest, importance and visual impact.

The structure of the newscast format has a lot to do with story selection as did news merits of the potential stories. This helps explain why gatekeepers do not always agree on specific stories but they do tend to agree on the kinds of stories that constitute a balanced news mix. The news cast format often calls for an approximate quota of stories from a variety of categories - national, business, foreign, sports and weather. TV3 and TV1 follow this format and their story selections varies from event centered and routine centered most of the time as practiced in the Mexican newsrooms of the spot news (nota del dia) model which prioritizes news reported on events as they happen (Table 2 Commonalities and Disparities among Media Organizations (From In-depth Interviews).

Table 2. Commonalities and Disparities among Media Organizations (From In-depth Interviews)

\begin{tabular}{|c|c|c|}
\hline Research Question & $\begin{array}{c}\text { Similarities/Commonalities } \\
\text { Between Media Organizations }\end{array}$ & $\begin{array}{c}\text { Differences/Disparities } \\
\text { Between Media Organizations }\end{array}$ \\
\hline $\begin{array}{l}1 \\
\text { Who makes decisions at } \\
\text { different levels of } \\
\text { production - } \\
\text { preproduction, } \\
\text { production and post- } \\
\text { production in the } \\
\text { making of news? }\end{array}$ & $\begin{array}{l}\text { Decisions are made collectively, } \\
\text { twice daily. Once in the morning } \\
\text { meeting and once in the evening } \\
\text { to determine the headlines. }\end{array}$ & $\begin{array}{l}\text { The difference is only in terms } \\
\text { of time as the Awani and TV1 } \\
\text { newsrooms have their meeting } \\
\text { at } 9 \text { am and } 5 \text { pm while TV3 } \\
\text { has theirs at } 10 \text { am and } 6 \text { pm. }\end{array}$ \\
\hline $\begin{array}{l}\text { What forces (internal / } \\
\text { external) have } \\
\text { influenced the decision } \\
\text { making process in the } \\
\text { newsrooms of the } \\
\text { broadcasting system? }\end{array}$ & $\begin{array}{c}\text { Internal: } \\
\text { Staff performance } \\
\text { Censorship } \\
\text { External: } \\
\text { Government guidelines } \\
\text { Stakeholders } \\
\text { Advertisement }\end{array}$ & $\begin{array}{c}\text { Internal: } \\
\text { Company's KPIs } \\
\text { Minister's interference } \\
\text { External: } \\
\text { Ratings } \\
\text { Complaints and legal action }\end{array}$ \\
\hline $\begin{array}{c}3 \\
\text { What government } \\
\text { policies influenced the } \\
\text { network's } \\
\text { programming? }\end{array}$ & $\begin{array}{c}\text { All policies - 1Malaysia, } \\
\text { Economic transformation } \\
\text { program, political transformation } \\
\text { program, Government } \\
\text { transformation program, NKRA }\end{array}$ & PEMANDU Projects \\
\hline
\end{tabular}


From the above results, there are several points of summary which can be made. The first, the decision making process in these three newsrooms are made by consensus by a group of people from the reporters, senior reporters, assignment editors, editors, heads of news and the bosses that have different designations in different organizations.

Secondly, there are two meetings on a daily basis, one in the morning to determine the news coverage while another in the evening to determine the headlines of the day.

Thirdly, there are internal and external factors that have influenced the decision making process in the newsrooms and what makes it more difficult is that fourthly, TV3 is the only newsroom that has a Putrajaya Appointee (internal factor) in the newsroom to 'help' make these decisions.

The fifth point is that, the TV1 newsroom runs on the government model while TV3 and Awani follow the professional model but with different approaches.

The sixth argument put forward is that all media organizations give coverage to all government policies launched by the Prime Minister as and when it happens. TV1 and TV3 take a very direct approach to this whereas Awani takes a 360 degree slant of reporting.

This study has also shown that while working in the newsrooms can be eventful with a lot adrenalin running on days where there is a big story, it is also fraught with difficulties and challenges, not least of which is the problem of communication between newsroom staff. Therefore, irrespective of which decision making model used in the newsrooms - the government model or the professional model, the communication or lack thereof when policies change, must be communicated clearly.

So in a nutshell, transformation in the newsrooms as the transformation programs is inevitable and demands agility, adaptability and efficiency from communication professionals. If professionalism in this industry is to be rationally refined, maintained, protected and advanced, then the reporters, editors and management in the position to do so must begin to reliably and systematically assess their own performance.

\section{References}

Bennett, W.L. (2007). News the Politics of Illusion. $7^{\text {th }}$ edition. Longman Classics in Political science. Pearson Education Inc.

Berkowitz, D. (1997). Social Meanings of News: A Text Reader. California: Sage Publications. International Educational and Professional Publisher.

Dimmick, J. and Coit, P. (1982). Levels of analysis in mass media decision making: A taxonomy, research strategy and illustrative data analysis. Communication Research 9 (1): 3-32.

Faridah I. (1995). Role conflict and role ambiguity among Malaysian journalists in newsroom decision-making. PhD dissertation, UPM. 
Faridah I. (2001). Predictors of Role Stress Among Malaysian Journalists in Newsroom Decision-Making Process. Jurnal Komunikasi. Jilid 17, 2001, p119-137.

Faridah I., Latiffah P., Chang P.K., Fuziah Kartini H.B., Badrul Redzuan A.H. and Wan Amizah W.M. (2011). Journalists and news sources: Implications on professionalism in war reporting. The Innovation Journal-The Public Sector Innovation Journal. Vol. 16 (3), 2011, Article 4.

Faridah I., Ali S., Chang P.K., Normah M. and Fauziah A. (2012). Striking a balance between science and arts: Mass media dilemma in reporting health and environmental issues. Asian Social Science 8 (5), 2012.

Gans, H.J. (1980). Deciding What's News. A study of CBS Evening News, NBC Nightly News, Newsweek and Time. New York: Vintage Books.

Gans, H.J. (2003). Democracy and the News. A Study of CBS Evening News, NBC Nightly News, Newsweek and Time. Oxford: Oxford University Press.

Gaziano, C. and Coulson, D.C. (1988). Effects of Newsroom management styles on journalists: A Case Study. Journalism Quarterly 65, pp 869-80.

Green, K. (1999). How newsroom failures limit readership gains. Australian Studies in Journalism 8: 18-36.

Gomez, E.T. (2004). The State of Malaysia: Ethnicity, Equity and Reform. London: Routledge Curzon.

Group Decision Making. (1984). The Center for the Study of Decision Making. London: Sage Publications Ltd.

Gutierrez, E,Wiggins, F. M and Williams, C.B. (1995). A Model of Ethical Decision Making from a Multicultural Perspective. http://www.highbeam.com/doc/1G1131609857.html . [19 $9^{\text {th }}$ December 2012].

Hachten, W. A. (2005). The Troubles of Journalism. A Critical Look at What's Right and Wrong with the Press. $3^{\text {rd }}$ Edition. London: Lawrence Erlbaum Associates Publishers.

Hallin, D. C. and Mancini, P. (Eds.) (2011). Comparing Media Systems beyond the Western World. Cambridge: Cambridge University Press.

Henningsen, D.D. and Henningsen, M.L.M. (2007). Dealing With Missing Information in Decision-Making Groups. Communication Research. Vol. 34, No 5: 507-525.

Johnson, K. G. (2004). Epistemology and responsibility of the mass media: A review of general semantics 61 (3): 663-675. http://search.proquest.com $\left[26^{\text {th }}\right.$ February 2013].

Joseph, T. (1983). Decision-making preferences and practices. Canadian Journal of Communication 9 (2): 37-48.

Khattab, U. (2004). Privileged culture and polarized public spheres: State broadcasting in Malaysia. Journal of Asian Research Center for Religion and Social Communication 2 (2): 1-7.

Lacy, S., Coulson, D.C. and Martin, H.J. (2004). Ownership and barriers to entry in non-Metropolitan Daily newspaper markets. Journalism and Mass Communication Quarterly. Summer 200481 (2): 327-342.

Lee, C. (2001). Telecommunications Reforms in Malaysia. Kuala Lumpur: Faculty of Economics \& Administration. University of Malaya.

Lowrey, W. and Chang W.W. (2010). The News Organization in uncertain times: Business or institution? Journalism \& Mass Communication Quarterly 87 (1): 41-61.

Media Prima Berhad.(2010). Retrieved from http://www.mediaprima.com.my/ $16^{\text {th }}$ October 2010. 
Morris, W.T. (1964). The analysis of management decisions. Revised edition. Hometown, Illinois: Richard D. Irwin, Inc.

Mustaffa K. Anuar. (2000). Malaysian Media and Democracy. Media Asia. Vol 27 No 1.

Napoli, P.M. and Zhaoxu Y.M. (2007). Media ownership regulations and local news programming on broadcast television: An empirical analysis. Journal of broadcasting \& electronic media. March 2007 V51 i1 p39 (19).

Netto, A. (2002). Media freedom in Malaysia: The challenge facing civil society. Media Asia. 29 (1): 17-23.

Overby, C.L. (1995). Needed in newsrooms: Time to think. American Journalism Review, 17 (6): 2.

Papandrea, F. (2006). Media diversity and cross media regulation. Prometheus 24 (3): 301-322.

Schudson (2002) p.17

Penyiaran, D. B. A. (1987). Persatuan Penyiar Kebangsaan Malaysia.

Pereira, C. 2008. News media and new media. Media Asia 35 (3).

Radio Television Malaysia (RTM). (2011). Retrieved from http://www.TV3.gov. my/TV3new/ $28^{\text {th }}$ January 2011.

Ramanathan, S. (2008). Malaysia's 2008 political tsunami: Hope for media liberalisation? Media Asia 35 (4): 233-240.

Roslina A.L. and Faridah I. (2012) A study on the decision making process in newsrooms and government policies under Dato' Sri Mohd Najib's Administration: a Comparison between RTM and Astro Awani. Jurnal Komunikasi; Malaysian Journal of Communication , 28 (2). pp. 205-226. ISSN 0128-1496.

Shoemaker, P.J. and Reese, S.D. (1996). Mediating the message: Theories of influences on mass media content. New York: Longman.

Schudson, M. (2002). The News Media as Political Institutions. Annual Review of Political Science. Vol. 5: 249-269 (Volume publication date June 2002) DOI: 10.1146/annurev.polisci.5.111201.115816.

Schultz, I. (2007). The journalistic gut feeling: Journalistic doxa, news habitus and orthodox news values. Journalism Practice 1 (2): 190-207.

Yesudhasan, T. J. and Wong Zhin-Seng, L. (2010). Media and public sphere: Representation of democracy in the Malaysian press. Media Asia 37 (2): 67-72.

Zaharom, N. and Mustafa, K.A. (2010). Ownership and control of the Malaysian media. World Association for Christian Communication.html. 1998. Retrieved from http://waccglobal.org/ $/ 5^{\text {th }}$ October 2010.

Zey, M. (1992). Decision Making: Alternatives to Rational Choice Models. London: Sage Publications. International Education and Professional Publisher. 